\title{
A study on a numerical simulation of the leakage and diffusion of hydrogen in a fuel cell ship
}

\author{
Feng Li ${ }^{1,3}$, Yupeng Yuan ${ }^{1,2,3}$, Xinping Yan ${ }^{3}$, Reza Malekian ${ }^{4}$, Zhixiong $\mathrm{Li}^{5}$ \\ 1. Reliability Engineering Institute, School of Energy and Power Engineering, Wuhan University of Technology, \\ Wuhan Hubei 430063, China; \\ 2. Department of Engineering, University of Cambridge, CB3 0FA, UK; \\ 3. National Engineering Research Center for Water Transport Safety, Wuhan University of Technology, Wuhan \\ Hubei 430063, China; \\ 4. Department of Electrical, Electronic and Computer Engineering, University of Pretoria, Pretoria, South Africa. \\ 5. School of Mechanical, Materials, Mechatronic and Biomedical Engineering, University of Wollongong, \\ Wollongong, NSW 2522, Australia.
}

\section{Highlights}

- The safety of hydrogen fuel cell ship is researched by a CFD simulation.

- The corners of fuel cell cabins are the areas with a higher concentration of hydrogen.

- Reasonable ventilation is the most effective solution to hydrogen safety in cabin.

\begin{abstract}
A hydrogen fuel cell has many advantages, such as no pollution, high efficiency, low noise and continuous operation. Therefore, it has the potential to be widely applied in both the power propulsion and power supply of a ship. However, the consequent hydrogen safety and leakage issues have attracted much attention and become key issues that need to be resolved urgently. In this paper, based on the component transportation and chemical reaction modules in Fluent software, a ferry is selected as the research object, and a diffusion model of the high pressure hydrogen leakage in a


cabin is established. The hydrogen concentration distributions at different leakage positions after the leakage occurs are obtained by making transient numerical calculations of the hydrogen leakage diffusion at the corresponding leakage positions in the cabin. At the same time, the effects of different ventilation conditions on the diffusion trend of hydrogen are analyzed. The simulation results have ascertained the optimal positions for hydrogen sensors and ventilations and it is hoped that these results can provide guidance for the design of a fuel cell ship that uses high pressure gaseous hydrogen.

Keywords: fuel cell ship; hydrogen; leakage diffusion; numerical simulation; concentration distribution

\section{Introduction}

As a major part of the globalized economy, the shipping industry has not only made a great contribution to the international economy and trade, but has also led to serious emission problems with regard to pollutants and greenhouse gases. According to some statistics, the $\mathrm{CO}_{2}$ emissions of the shipping industry account for approximately $3 \sim 5 \%$ of global $\mathrm{CO}_{2}$ emissions, while the $\mathrm{SO}_{\mathrm{X}}$ emissions exceed $5 \%[1,2]$. Due to the hydrogen fuel cell's advantages, which include environmental protection, high energy efficiency and exceptional reliability, it has gradually attracted a great deal of attention in the shipping industry [3]. Moreover, these cells are distinguished from other clean energies (such as solar energy, wind energy, and hydro energy) by their characteristics of high energy density, and high stability and the fact that they are not easily affected by the environmental factors. Therefore, the application of hydrogen fuel cells in ships has promoted the development of clean energy vessels $[4,5]$. At present, there are many applications of hydrogen 
fuel cells in ships, which are summarized in Table 1 [6-8].

Table 1. Application cases of hydrogen fuel cells in ships

\begin{tabular}{|c|c|c|c|}
\hline Year & Nationality & Vessel & Characteristic \\
\hline 2002 & China & Fuyuan One & $\begin{array}{l}\text { Fuyuan One is a fuel cell yacht: propulsion power } \\
\text { of } 400 \mathrm{~W} \text {, speed of } 7 \mathrm{~km} / \mathrm{h} \text {. }\end{array}$ \\
\hline 2005 & China & Tianxiang One & $\begin{array}{l}\text { Tianxiang One is an experiment ship: propulsion } \\
\text { power of } 2 \mathrm{~kW} \text {, speed of approximately } 7 \mathrm{~km} / \mathrm{h} \text {. }\end{array}$ \\
\hline 2006 & $\begin{array}{l}\text { Germany and } \\
\text { other members of } \\
\text { the European } \\
\text { Union }\end{array}$ & Alsterwasser & $\begin{array}{l}\text { Alsterwasser is the world's first operating fuel } \\
\text { tanker, which can carry more than } 100 \text { people and } 50 \\
\mathrm{~kg} \text { of hydrogen fuel: propulsion power of } 100 \mathrm{~kW} \text {, } \\
\text { sailing for } 2 \sim 3 \text { days without refueling }\end{array}$ \\
\hline 2009 & $\begin{array}{l}\text { Norway and } \\
\text { Germany }\end{array}$ & Viking Lady & $\begin{array}{l}\text { Viking Lady, is the vessel passed the marine fuel cell } \\
\text { certification of Det Norske Veritas: fuel cell } \\
\text { generation power of } 320 \mathrm{~kW}\end{array}$ \\
\hline 2015 & Japan & & $\begin{array}{l}\text { It is the first Japanese fuel cell ship, which was a } \\
\text { fishing vessel equipped with } 450 \mathrm{~L} \text { of hydrogen fuel: } \\
\text { speed of up to } 37 \mathrm{~km} / \mathrm{h} \text {, sailing for } 2 \mathrm{~h} \text { without } \\
\text { refueling }\end{array}$ \\
\hline
\end{tabular}

In 2016, Sandia National Laboratories, the Red and White Fleet, and the Elliott Bay Design Group jointly carried out the zero-emission, high-speed, fuel cell passenger ship project, "SFBREEZE”, in the San Francisco Bay, which had a maximum design speed of $35 \mathrm{~nm} / \mathrm{h}$. To data, a number of related feasibility study has been completed $[9,10]$. Although a lot of research has been carried out on power system design, energy efficiency improvement and control, benefit analysis and energy management strategies [11-20], and the prototype fuel cell ship has already demonstrated the ability to be used as an actual ship, a large-scale application is still some way off. During the various studies and attempts to popularize and apply the technology of a fuel cell ship, the high risks associated with hydrogen has been the major concern; therefore, safety is one of the key technologies that urgently needs to be solved in the development of a hydrogen fuel cell ship [21].

Hydrogen has the following characteristics: easy leakage and diffusion; low ignition energy; 
large potential for a fuel explosion; and large explosion energy [22]. The ignition volume fraction range is $4 \sim 74 \%$, the explosion volume fraction range is $18 \sim 59 \%$, and the minimum ignition energy is $0.02 \mathrm{~mJ}$ [23], which cause a certain level of risk when a hydrogen fuel cell is being applied to a ship. In order to meet a ship's endurance and power requirements, the hydrogen storage capacity on a fuel cell ship needs to be substantial. However, a ship is a large-scale, powerful piece of equipment, which has a long service life and works in a relatively harsh and complex environment. Moreover, once the equipment has been in operation for a long time, it is difficult to avoid the aging process, and maintenance issues might be neglected in a hydrogen fuel cell ship. If problems relating to the sealing of the hydrogen supply pipelines and valves arise, and the pipelines are damaged due to a collision, resulting in a hydrogen leakage and the consequent fire and explosion, there would be extremely serious consequences.

At present, research on hydrogen leakage diffusion mainly consists of experimental studies and numerical simulations $[24,25]$. Due to the high risk associated with hydrogen and the high cost of conducting related experiments, experimental studies on hydrogen leakage diffusion are rare. The numerical simulation is still the mainstream method currently used to study the process of hydrogen leakage diffusion, and computational fluid dynamics (CFD) software is widely used in this respect.

General CFD software include Fluent, FlACS, CFX, STAR-CD, PHOENICS, etc. Many researchers have done these relevant studies using experiment or simulation. Some useful conclusions were obtained, which are summarized in Table 2. 
Table 2. Overview on hydrogen leakage, diffusion and explosion

\begin{tabular}{|c|c|c|c|c|}
\hline Scenario & Author & Object & Method & Description and conclusions \\
\hline \multirow{9}{*}{$\begin{array}{l}\text { Leakage and } \\
\text { diffusion }\end{array}$} & $\begin{array}{l}\text { Michael R. } \\
\text { Swain [26] }\end{array}$ & $\begin{array}{l}\text { Simple } \\
\text { geometric } \\
\text { spaces }\end{array}$ & $\begin{array}{l}\text { Simulation and } \\
\text { experimental }\end{array}$ & $\begin{array}{l}\text { The leakage diffusion test of hydrogen could be } \\
\text { replaced by helium in a simple geometric } \\
\text { space. }\end{array}$ \\
\hline & $\begin{array}{l}\text { H.Wilkening } \\
\text { [29] }\end{array}$ & $\begin{array}{l}\text { Hydrogen } \\
\text { pipeline }\end{array}$ & $\begin{array}{l}\text { Simulation/ } \\
\text { CFD-ACE }\end{array}$ & $\begin{array}{l}\text { The hydrogen leakage was rapid and the hazard } \\
\text { area formed by hydrogen was smaller than one } \\
\text { caused by natural gas. }\end{array}$ \\
\hline & $\begin{array}{c}\text { Fotis Rigas } \\
\text { [30] }\end{array}$ & $\begin{array}{l}\text { Hydrogen } \\
\text { storage } \\
\text { system }\end{array}$ & $\begin{array}{l}\text { Simulation/ } \\
\text { CFX }\end{array}$ & $\begin{array}{l}\text { The damage caused by the leakage of liquid } \\
\text { hydrogen was more serious than that of high- } \\
\text { pressure hydrogen. }\end{array}$ \\
\hline & $\begin{array}{l}\text { D. Schmidt } \\
\text { [31] }\end{array}$ & $\begin{array}{l}\text { Urban } \\
\text { buildings }\end{array}$ & $\begin{array}{l}\text { Simulation/ } \\
\text { Fluent }\end{array}$ & $\begin{array}{l}\text { Considered the gas leakage rate, leakage time, } \\
\text { leakage amount, local wind speed, wind } \\
\text { direction and buoyancy. The size and shape of } \\
\text { the hydrogen cloud were simulated. }\end{array}$ \\
\hline & $\begin{array}{l}\text { Héctor A. } \\
\text { Olvera [32] }\end{array}$ & $\begin{array}{c}\text { Urban } \\
\text { buildings }\end{array}$ & $\begin{array}{l}\text { Simulation/ } \\
\text { STAR-CD }\end{array}$ & $\begin{array}{l}\text { The risk to the surrounding environment } \\
\text { caused by a hydrogen leakage would be far } \\
\text { more serious than a leakage of natural gas. }\end{array}$ \\
\hline & $\begin{array}{l}\text { A.G. } \\
\text { Venetsanos } \\
\text { [34] }\end{array}$ & $\begin{array}{l}\text { Fuel cell } \\
\text { vehicle }\end{array}$ & $\begin{array}{c}\text { CFD } \\
\text { Simulation }\end{array}$ & $\begin{array}{l}\text { The CFD method was reliable for the study of } \\
\text { hydrogen leakage diffusion. }\end{array}$ \\
\hline & $\begin{array}{c}\text { Jongrak Choi } \\
{[35]}\end{array}$ & $\begin{array}{l}\text { Fuel cell } \\
\text { vehicle }\end{array}$ & $\begin{array}{l}\text { Simulation/ } \\
\text { STAR-CCM }\end{array}$ & $\begin{array}{l}\text { The flammable zone of hydrogen follows a } \\
\text { non-linear growth during the incubation period } \\
\text { after a leakage. Furthermore, the ventilation } \\
\text { equipment can delay the accumulation of large } \\
\text { amounts of hydrogen. }\end{array}$ \\
\hline & $\begin{array}{l}\text { Yanlei Liu } \\
\text { [36] }\end{array}$ & $\begin{array}{l}\text { Fuel cell } \\
\text { vehicle }\end{array}$ & $\begin{array}{l}\text { Simulation/ } \\
\text { Fluent }\end{array}$ & $\begin{array}{l}\text { The simulation results ascertained the best } \\
\text { positions for hydrogen sensors in a vehicle. }\end{array}$ \\
\hline & $\begin{array}{c}\text { Eunjung Kim } \\
\text { [38] }\end{array}$ & $\begin{array}{l}\text { Hydrogen } \\
\text { refueling } \\
\text { station }\end{array}$ & $\begin{array}{l}\text { Simulation/ } \\
\text { FLACS }\end{array}$ & $\begin{array}{l}\text { The simulation results provided } \\
\text { recommendations for the safe distance design } \\
\text { of facilities in a hydrogen refueling station. }\end{array}$ \\
\hline \multirow{2}{*}{$\begin{array}{c}\text { Diffusion and } \\
\text { explosion }\end{array}$} & $\begin{array}{l}\text { K. Takenoa } \\
\text { [33] }\end{array}$ & $\begin{array}{l}\text { Fuel cell } \\
\text { vehicle }\end{array}$ & $\begin{array}{l}\text { Simulation and } \\
\text { experimental }\end{array}$ & $\begin{array}{l}\text { The explosive power of hydrogen depended on } \\
\text { the pre-mixed volume fraction of hydrogen-air } \\
\text { and turbulence characteristics before ignition. }\end{array}$ \\
\hline & $\begin{array}{c}\text { Jingyuan Li } \\
\text { [37] }\end{array}$ & $\begin{array}{l}\text { Hydrogen } \\
\text { refueling } \\
\text { station }\end{array}$ & $\begin{array}{l}\text { Simulation/ } \\
\text { FLACS }\end{array}$ & $\begin{array}{l}\text { The hydrogen explosion intensity is enhanced } \\
\text { significantly by an increase of congestion and } \\
\text { wind speed. }\end{array}$ \\
\hline $\begin{array}{l}\text { Diffusion and } \\
\text { ignition }\end{array}$ & $\begin{array}{l}\text { Shirvill C. L. } \\
\text { [27] }\end{array}$ & $\begin{array}{l}\text { Hydrogen } \\
\text { pipeline }\end{array}$ & Experimental & $\begin{array}{l}\text { The results validated both the hydrogen cloud } \\
\text { model and hydrogen jet model. }\end{array}$ \\
\hline Jet fire & $\begin{array}{c}\text { Robert W. } \\
\text { Schefer [28] }\end{array}$ & $\begin{array}{l}\text { Hydrogen } \\
\text { pipeline }\end{array}$ & Experimental & $\begin{array}{l}\text { Setting obstacles correctly could reduce the } \\
\text { damage to surrounding areas caused by a jet } \\
\text { fire and delay an explosion. }\end{array}$ \\
\hline
\end{tabular}


According to the ignition status, the aforementioned studies of hydrogen leakage can be divided into leakage and diffusion research and fire and explosion research. These generally occur in time order, i.e., a fire and explosion will not occur until the concentration of hydrogen reaches a certain level. With regard to research techniques, the experimental method should be complementary to the numerical simulation method. Although the experimental method is costly and dangerous, the validity and applicability of various mathematical models of hydrogen leakage need to be verified by experiments. Subsequently, the verified mathematical model can be utilized to conduct a numerical simulation study through packaging and combination by software. The main research objects for hydrogen leakage have included a hydrogen fuel cell automobile parking lot, hydrogen fuel cell automobile cabin and hydrogen refueling station building. The risk of an accident is related to a number of factors, including the hydrogen phase, the initial pressure, the size of the leakage hole, the sealing of the leakage area, the wind speed and direction, the ventilation equipment, the temperature, the obstacle, the arrangement of facilities in the area and the ignition conditions. Through modeling a specific case and setting the corresponding boundary conditions, the accident process can be simulated after the hydrogen leakage. Moreover, studying the effects of certain factors related to the consequences of an accident can provide guidance for relevant safety measures and accident prevention.

Currently, few studies has been conducted into the hydrogen leakage diffusion in the shipping industry. Moreover, the amount of electrical equipment in a ship is substantial, and the hydrogen storage capacity is high. Consequently, the safety hazards and accident levels in a ship are much higher than those in an automobile. In addition, the risk to a ship is much greater than that to a hydrogen refueling station because of the sealing of a ship's cabin. Specifically, once a hydrogen 
safety accident occurs, it is more difficult for rescue measures to be carried out. The cabin environment of a ship is very different to those of previous research objects and the safety design and prevention measures used for these objects cannot be transferred to a ship. Therefore, the study of the hydrogen leakage of a ship's fuel cell is of great importance.

In this paper, the process of hydrogen leakage from the fuel cell cabins of a hydrogen fuel cell ship is numerically simulated by Fluent software. The effects of different leakage positions on the hydrogen concentration field in a cabin are analyzed by transient numerical calculations. At the same time, the influences of different ventilation conditions in cabins on the hydrogen diffusion trend are analyzed and verified by simulation; this provides guidance for the layout of hydrogen sensors and the ventilation design. Unlike previous studies on hydrogen leakage, this paper takes a different approach in making the ship the research object and taking the cabin layout into account. Moreover, a transient simulation can show the process of hydrogen leakage intuitively. The structure of this paper is as follows. In Section 2, the research object is introduced in detail, the fluid domain model is established, the meshing is generated, and the boundary conditions in Fluent software are selected and calculated. In Section 3, the simulation results of the hydrogen leakage diffusion at different leakage positions and under different ventilation conditions are described and analyzed. In Section 4 , the research findings of this paper are summarized.

\section{The Research Object and Boundary Conditions}

\subsection{The Research Object}

In this paper, a hydrogen fuel cell ship from the "SF-BREEZE" project (mentioned in Section 1) is selected as the study object, which is currently in the research and development stage [10]. The 
overall design model of the ship is shown in Figure 1 . The maximum design speed is $35 \mathrm{~nm} / \mathrm{h}$, the capacity is 150 seats, the ship's length and width are approximately $30 \mathrm{~m}$ and $10 \mathrm{~m}$ respectively, and the ship is a twin-hull vessel. The ship consists of a top floor, deck and bottom floor. The top floor has a cockpit, hydrogen exhaust pipes, hydrogen storage tanks and accessories, and other facilities. The bottom floor has propulsion motors, gearboxes, batteries, heat exchangers, fire pumps, and other equipment. The ship's power is completely provided by 40 sets of $4 \times 30 \mathrm{~kW}$ proton exchange membrane fuel cell packs, which located in the fuel cell cabins on the deck, with a total installed power of $4.92 \mathrm{MW}$ (including $120 \mathrm{~kW}$ of reserve power). The deck consists of a bow cabin, passenger cabin, control cabin, fuel cell cabins and stern cabin, as shown in Figure 2. The fuel cell cabins are two separate cabins on the left and right, each with 20 fuel cell packs. There are two converters on the left and right sides of the control cabin, and a power distribution cabinet in the center. There is a bathroom and a bar on one side of the passenger cabin close to the control cabin, with 150 passenger seats. Considering that the high-pressure gas storage is the most common hydrogen storage technology, the numerical simulation study of the high-pressure hydrogen leakage diffusion in the cabins of a fuel cell ship is conducted using with this ship's cabin layout. For hydrogen storage system, the initial design of liquid hydrogen is replaced by high pressure hydrogen storage tank, which is easier to implement and realize. Therefore, the results of this simulation are different from those of initial design. In order to simulate more extreme cases, the storage pressure of the high-pressure hydrogen storage tank is selected to be $20 \mathrm{MPa}$. After the primary pressure reducing valve switching on, the cabin pipeline pressure decreases to $10 \mathrm{MPa}$; and then, after the secondary pressure reducing valve switching on, hydrogen enters the fuel cell and the pressure becomes $0.1 \mathrm{MPa}$. The initial pressure of hydrogen leakage is $10 \mathrm{MPa}$, if assuming the hydrogen 
leakage is caused by the cracking, or breakage of the hydrogen supply pipelines, or valves in the fuel cell cabins. Since the whole calculation process is conducted using transient numerical calculations, in order to ensure that the simulated hydrogen leakage diffusion process takes a certain length of time, and to minimize the calculation time and save calculation resources, the described ship's cabin model is simplified with minimum effects on the calculation results. The model on twodimensional unstructured meshes is shown in Figure 3, with a total number of 33,973 grids. The mesh statistics is shown in Figure 4.

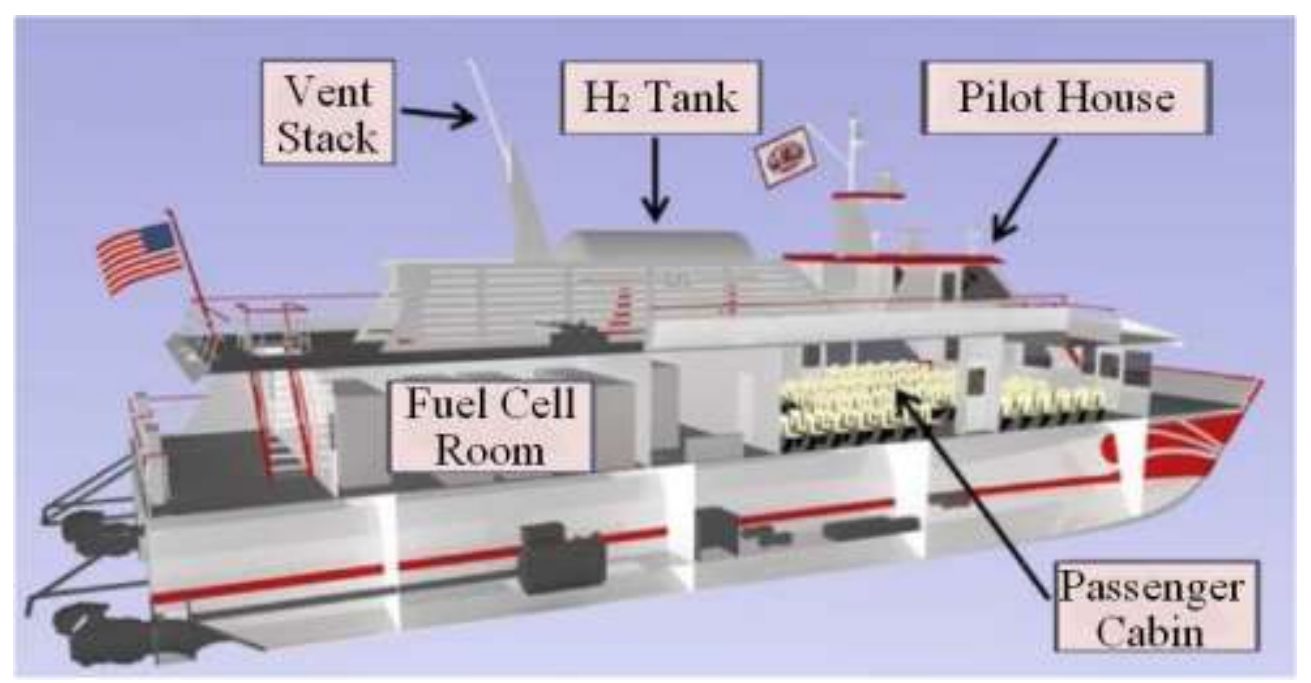

Figure 1. The "SF-BREEZE" fuel cell ship [10]

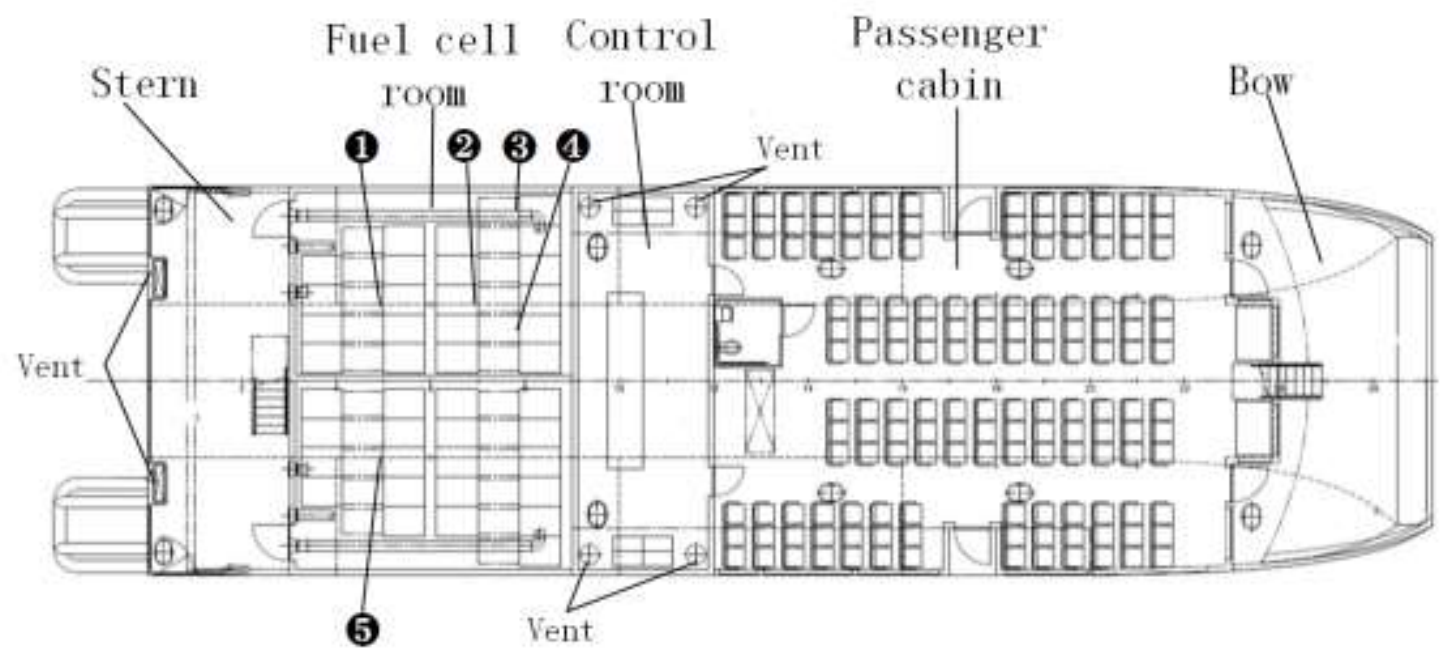

Figure 2. A schematic diagram of the hydrogen leakage diffusion in the deck cabins [10] 


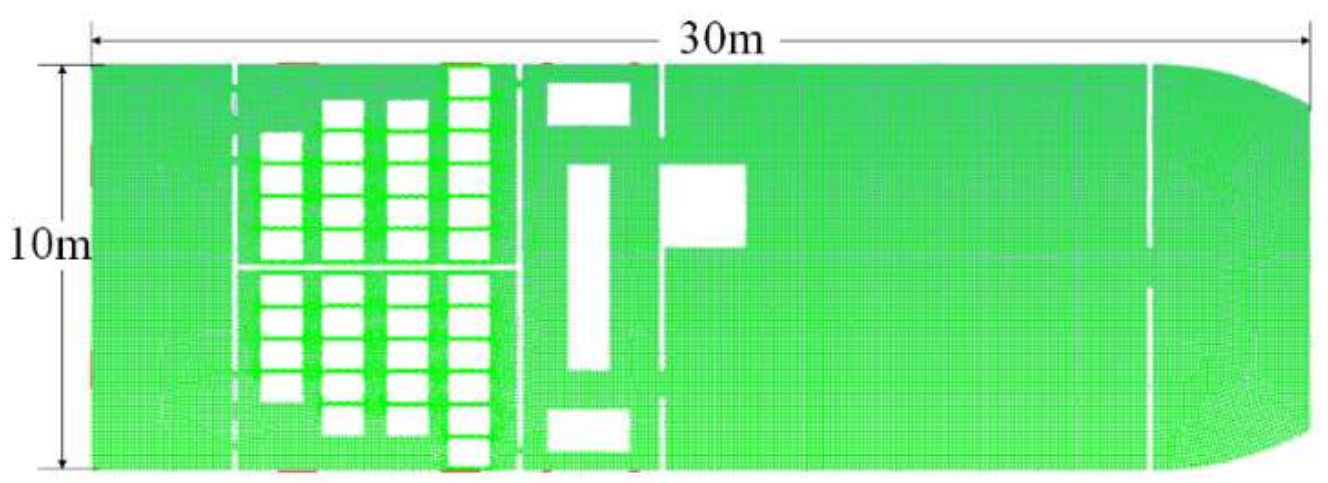

Figure 3. The meshing model

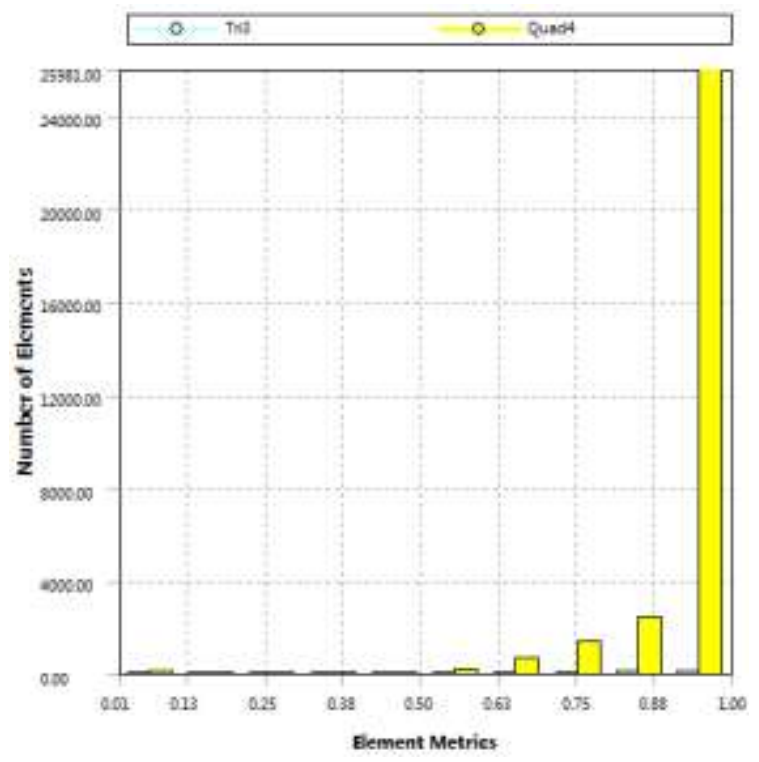

Figure 4. Mesh statistics

\subsection{The Boundary Conditions and Leakage Calculation}

According to Figure 2, there are 2 vents in the stern cabin, located at the end of the ship, each with a diameter of $1 \mathrm{~m}$. Furthermore, there are 4 vents in the control cabin, 2 at each side of the ship, each with a diameter of $0.25 \mathrm{~m}$. The initial environmental pressure is the standard atmospheric pressure, and the temperature is $300 \mathrm{~K}$. In order to make it easy to calculate the hydrogen diffusion between cabins easily, it is assumed that the cabins are connected to each other by the gaps, doors and windows, and are simplified in the modeling process, as shown in Figure 3.

The hydrogen leakage positions are in the fuel cell cabins, and the leakages occur at the 
hydrogen supply pipelines or valves. There are 40 fuel cell packs in total. In this paper, 5 typical leakage positions are selected for the numerical simulation analysis of the hydrogen leakage diffusion; these are marked as No.1, No.2, No.3, No.4 and No.5 leakage holes, as shown in Figure 2.

Considering that most of the initial stages of a high-pressure hydrogen leakage diffusion are sub-expansion jets, the hydrogen needs to further expand to the ambient pressure outside the leakage holes. The mass flow rate calculation method for high-pressure hydrogen sub-expansion jets can be derived from the Abel-Noble equation of state (AN-EOS) and the energy and mass conservation equations [39], as shown in Equations (1-6).

$$
\begin{gathered}
\rho_{1}=\frac{p_{1}}{b p_{1}+R_{H_{2} T_{1}}} \\
\left(\frac{\rho_{1}}{1-b \rho_{1}}\right)^{\kappa-1}=\left(\frac{\rho_{3}}{1-b \rho_{3}}\right)^{\kappa-1}\left[1+\frac{\kappa-1}{2\left(1-b \rho_{3}\right)^{2}}\right] \\
\frac{T_{1}}{T_{3}}=1+\frac{\kappa-1}{2\left(1-b \rho_{3}\right)^{2}} \\
\rho_{3}=\frac{p_{3}}{b p_{3}+R_{H_{2}} T_{3}} \\
u_{3}=\sqrt{\frac{\kappa p_{3}}{\rho_{3}\left(1-b \rho_{3}\right)}} \\
q_{m}=\frac{1}{4} \pi d^{2} \rho_{3} u_{3}
\end{gathered}
$$

where $\rho_{1}$ represents the initial hydrogen density, $p_{1}$ represents the initial pressure, which is set to be $10 \mathrm{MPa}, b=7.69 \times 10^{-3}$ represents the Abel-Noble residual capacity coefficient, $R_{\mathrm{H}_{2}}=$ $4.12424 \times 10^{3} \mathrm{~J} /(\mathrm{kg} \cdot \mathrm{K})$ represents the hydrogen gas constant, $T_{1}$ represents the initial temperature, which is set to be $300 K, \kappa$ represents the adiabatic index, which is set to be 1.4 , $\rho_{3}, T_{3}, p_{3}$ and $u_{3}$ represent the hydrogen density, the temperature, the pressure and the hydrogen velocity at the actual leakage hole respectively, $q_{m}$ represents the mass flow rate, and $d$ represents the diameter of the leakage hole, which is set to be $10 \mathrm{~mm}$. As a result, the initial hydrogen 
density, $\rho_{1}=7.6 \mathrm{~kg} / \mathrm{m}^{3}$, and the leakage mass flow rate of hydrogen, $q_{m}=0.467 \mathrm{~kg} / \mathrm{s}$, are obtained by calculation.

In this paper, the geometric model and mesh statistics of the fuel cell ship are first established. Then, the leakage mass flow of hydrogen can be calculated using the AN-EOS model. Next, the mesh model is imported into the Fluent software. Finally, the boundary conditions and fluid control equations are set. By setting the hydrogen fraction monitor, the hydrogen concentration during the entire leakage period can be obtained. The main equations selected in the Fluent software include the continuity equation, momentum equation, energy equation and material diffusion equation. Furthermore, the Realize $k-\varepsilon$ equation is utilized in the turbulence model [40]. In the process of transient numerical calculation, the time step is fixed to be $0.01 \mathrm{~s}$. The number of iterations can be calculated according to the time step and simulation time. For example, if the simulation time is 5 $\mathrm{s}$, the number of time steps should be set to be 500. In this paper, the maximum simulation time is $300 \mathrm{~s}$. When the residual value tends to be stable and less than $1 \times 10^{-3}$, the result is considered to be convergent.

\section{Results and Analysis}

\subsection{A Simulation of the Hydrogen Leakage Diffusion at Different Leakage Positions}

Taking into account the symmetry of the left and right fuel cell cabins, in order to select more representative leakage positions, 4 leakage holes are selected in the left cabin, with No.1, No.3 and No.4 in the stern direction, and No.2 in the bow direction. In addition, the No.5 leakage hole is selected in the stern direction of the right cabin. After the leakage occurs, the volume concentration distributions of hydrogen at different leakage positions in the cabins are shown in Figures 5-9. 


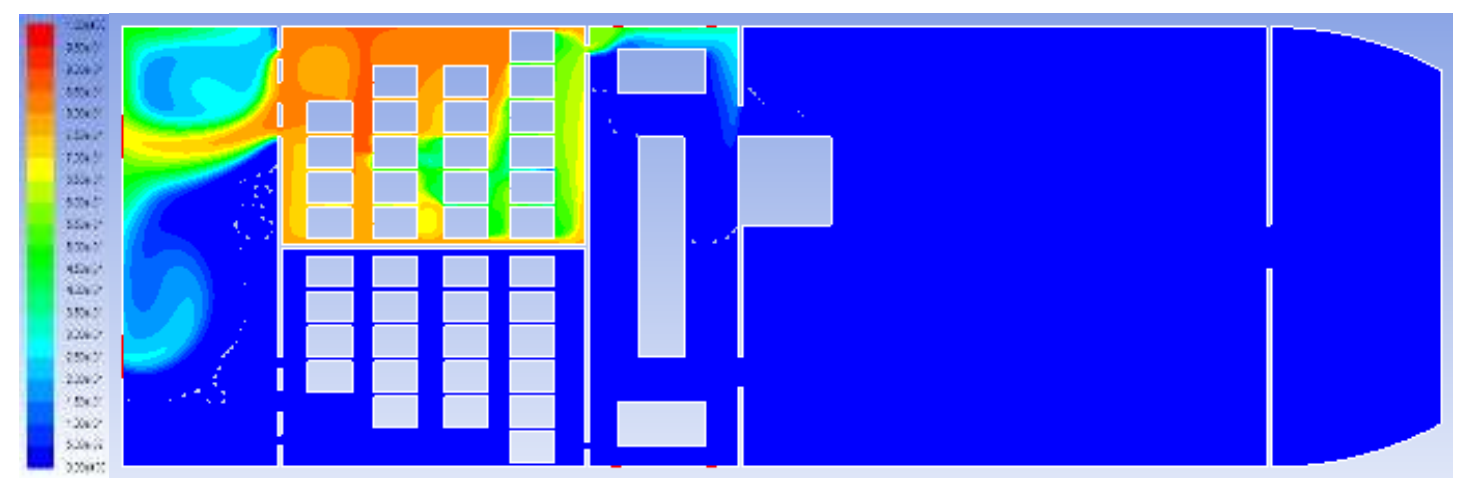

Figure 5. The hydrogen concentration distribution after No.1 hole leaks at $t=5 \mathrm{~s}$

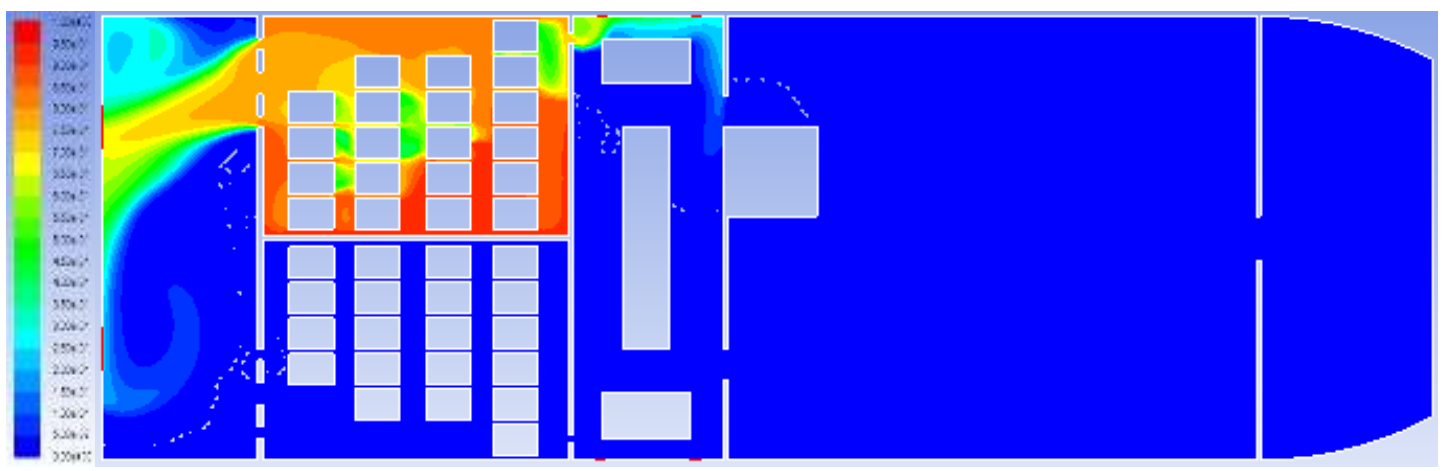

Figure 6. The hydrogen concentration distribution after No.2 hole leaks at $t=5 \mathrm{~s}$

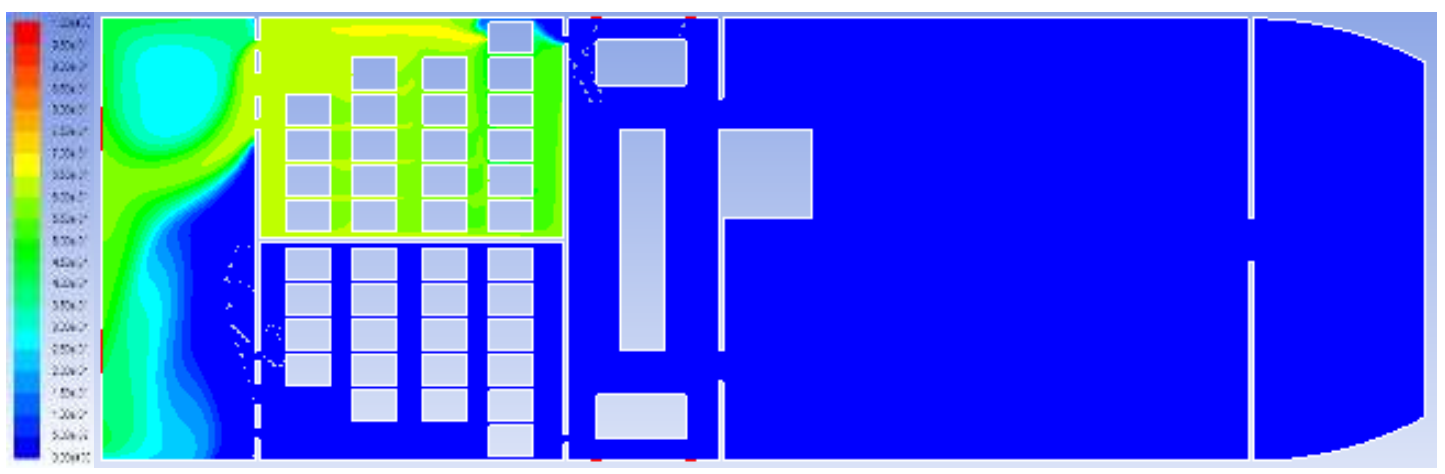

Figure 7. The hydrogen concentration distribution after No.3 hole leaks at $t=5 \mathrm{~s}$

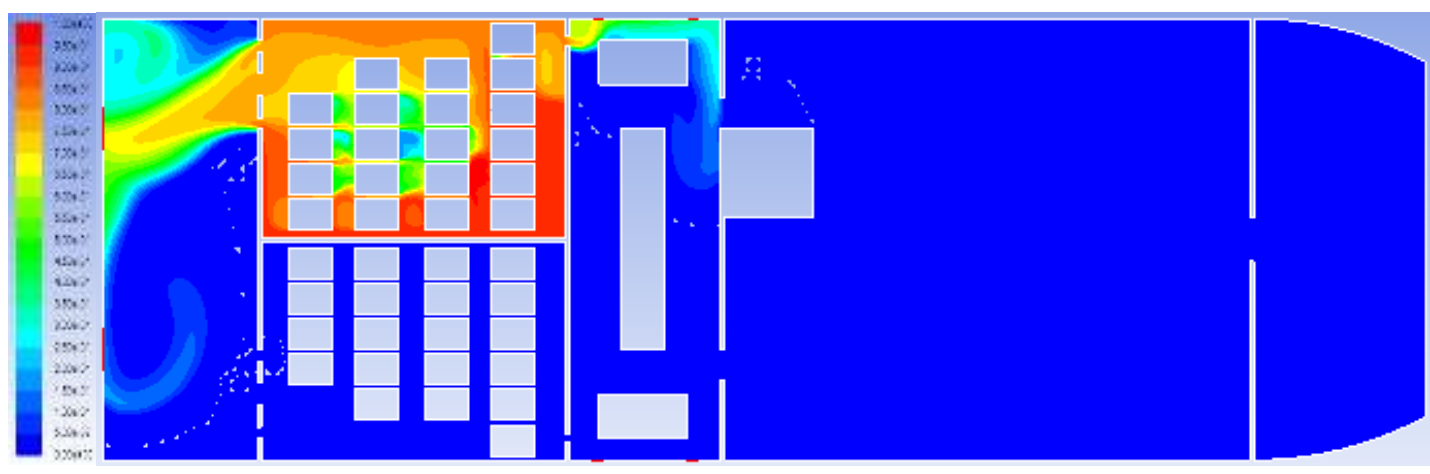

Figure 8. The hydrogen concentration distribution after No.4 hole leaks at $t=5 \mathrm{~s}$ 


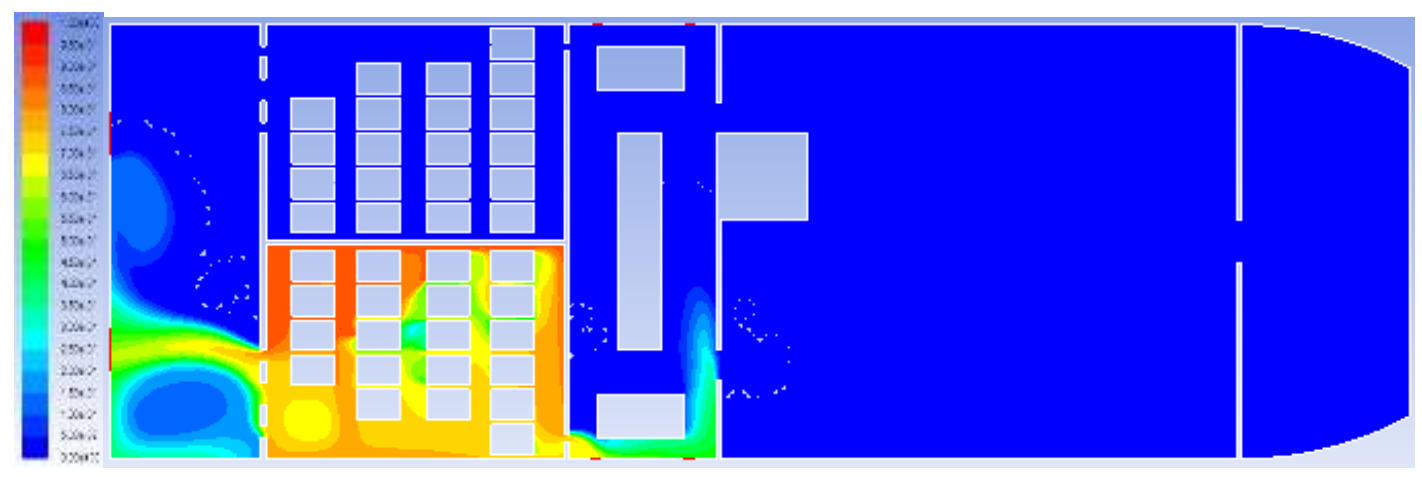

Figure 9. The hydrogen concentration distribution after No.5 hole leaks at $t=5 \mathrm{~s}$

As can be seen from Figures 5-8, at $t=5 \mathrm{~s}$, the left fuel cell cabin is almost filled with hydrogen, which reaches the flammability concentration range of $4 \% \sim 74 \%$. At the walls and corners close to the cabin, the accumulated hydrogen concentrations actually reach $100 \%$. With the exception of the No.3 leakage hole, the hydrogen from all the other leakage holes has already begun to partly diffuse to the control cabin at this time. In the meantime, the hydrogen from all the leakage holes has significantly diffused to the stern cabin and been exhausted through the vents. In Figure 9 , the concentration distribution of the No.5 hole in the right cabin is substantially symmetrical with that of the No.1 hole in Figure 5.

According to the simulation results above, at $t=5 \mathrm{~s}$, the fuel cell cabins have already become explosion hazard areas; therefore, hydrogen sensors should be installed at the walls and corners in these cell cabins. Any hydrogen leakage needs to be detected and an alarm needs to be raised in advance to help the relevant personnel take appropriate emergency measures. The hydrogen concentration in the cabin after the No.3 hole leaks is significantly lower than that after the other positions leak. In addition, the hydrogen diffuses more quickly from the No.3 hole, and there is no diffusion from this hole to the control cabin. This is because No.3's leakage is in the stern direction and passes fewer obstacles than the other leakage holes during venting.

Overall, the layout design of a cabin used for the storage of high-pressure hydrogen cannot 
completely avoid the accumulation of hydrogen in the cabin when a leakage occurs. In a relatively short time, the hydrogen will diffuse to the other cabins, such as the control cabin that has more electrical equipment and is more likely to cause a spark, which will result in a more serious security risk. Therefore, when the design and layout of a cabin is taking place, the ventilation from the fuel cell cabins to the outboard area should be ensured, and the number of obstacles between the fuel cell cabins and stern cabin should be minimized. In the fuel cell cabins, control cabin and stern cabin, any equipment that can cause a spark needs to be removed, exposed plugs should be prohibited, and all electrical equipment needs to be explosion-proof and grounded. As the must-pass passage of the hydrogen exhaust, all equipment and manual operations that may cause a fire and hydrogen explosion need to be removed from the stern cabin. Since the control cabin is close to the fuel cell cabins, a number of hydrogen sensors should be arranged in this cabin. Once a hydrogen leakage is detected in the control cabin, the alarm level has to be increased and emergency measures have to be taken.

\subsection{A Simulation of the Hydrogen Leakage Diffusion under Different Ventilation Conditions}

The ship's cabin is a relatively closed and complex environment, which is not conducive to the dissipation of hydrogen. A large quantity of hydrogen will accumulate in the cabin after a leakage, which may lead to an explosion at any time. Therefore, the ventilation condition of the cabins will be one of the most important factors regarding the safety of a hydrogen fuel cell ship. Based on the original ventilation design of the fuel cell ship, 4 kinds of ventilation conditions are selected to carry out the numerical simulation of the hydrogen diffusion process in cabins. Condition 1: the natural ventilation condition; Condition 2: keeping the original 2 natural vents in the stern cabin and 4 vents in the control cabin, and adding 2 natural vents with a diameter of $1.2 \mathrm{~m}$ in the passenger cabin, with 
1 on the left and the other on the right; Condition 3: maintaining the original natural vents, and adding 4 natural vents with a diameter of $1 \mathrm{~m}$ in the fuel cell cabins, with 2 on each side; Condition 4: maintaining the original natural vents, and adding 4 mechanical vents with a diameter of $1 \mathrm{~m}$ in the fuel cell cabins, with 2 on each side. In Condition 4, the additional 4 mechanical vents adopt the corresponding control schemes. If the hydrogen sensors detect that there is a hydrogen leakage in the left cabin, the 2 ventilators on the left side will open automatically. Furthermore, if a leakage is detected in the right cabin, the 2 ventilators on the right will open automatically. The outlet flow rate of the mechanical vent is set to $10 \mathrm{~m} / \mathrm{s}$. The No.1 leakage hole in the stern direction is selected as the leakage position, so that the ventilators on the left will open when Condition 4 is simulated. In order to compare the situations of hydrogen entering the control cabin and passenger cabin under the 4 kinds of ventilation conditions, the No.1 and No.2 detection points are set at the entrance of the control cabin, and the No.3 and No.4 detection points are set at the entrance of the passenger cabin. Figures 10-13 show the changes to the hydrogen concentration at the 4 detection points under the 4 different ventilation conditions 5 minutes after the hydrogen leakage has occurred.

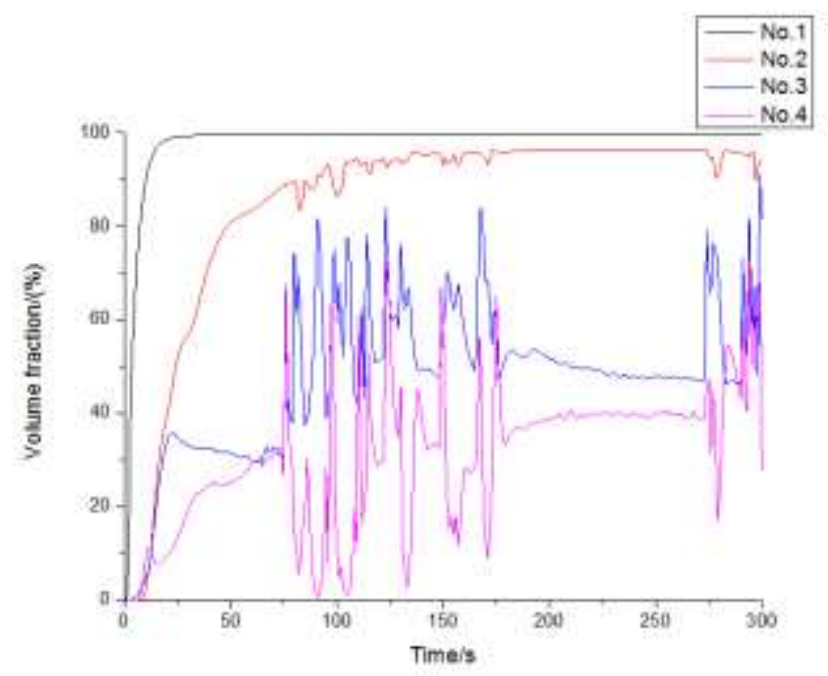

Figure 10. Changes to the hydrogen concentration at the detection points under Condition 1 


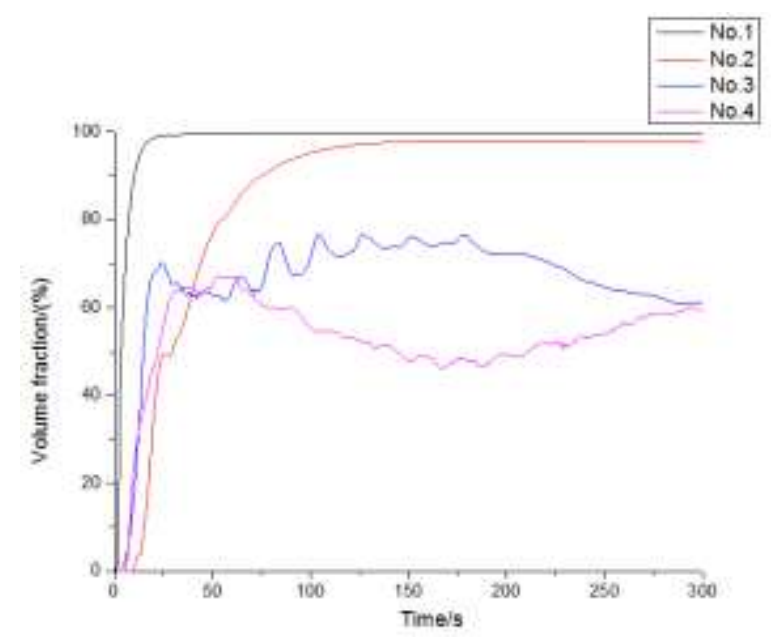

Figure 11. Changes to the hydrogen concentration at the detection points under Condition 2

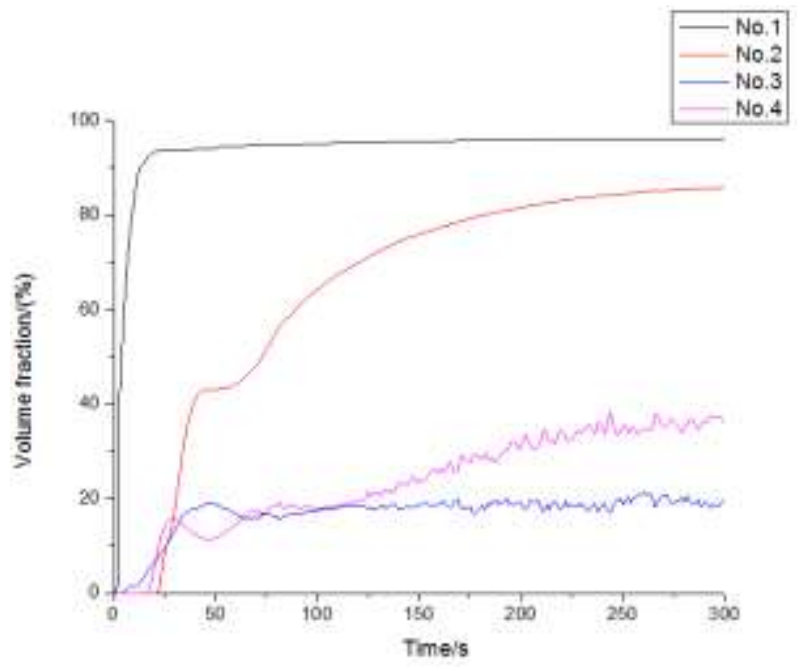

Figure 12. Changes to the hydrogen concentration at the detection points under Condition 3

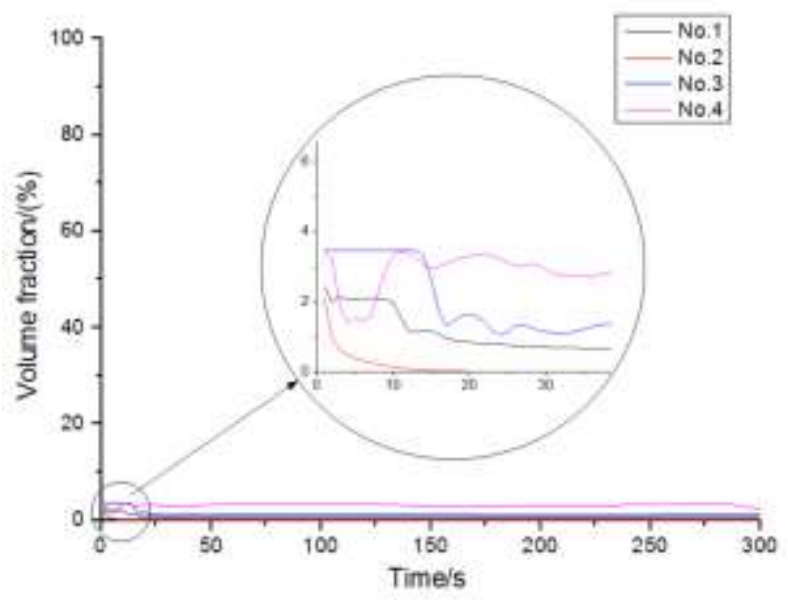

Figure 13. Changes to the hydrogen concentration at the detection points under Condition 4

As can be seen in Figure 10, under the original ventilation condition, the concentration of 
hydrogen entering the control cabin increases rapidly, within approximately $10 \mathrm{~s}$, to almost $100 \%$, and then maintains the same level. Then the air in the control cabin is almost exhausted. An explosion cannot happen at this concentration due to the lack of an oxidizer. However, it can lead to people in the area suffering from asphyxia. The concentration of hydrogen entering the passenger cabin fluctuates a great deal, and achieves a flammability range of $4 \% \sim 74 \%$. Therefore, any spark or static electricity may cause a fire and explosion, which will lead to a serious safety hazard.

In Condition 2, the original ventilation condition is improved, and 2 vents are added in the passenger cabin. As shown in Figure 11, the change to the concentration of hydrogen entering the control cabin is basically the same as that under the original ventilation condition. Compared with Condition 1, the concentration of hydrogen entering the passenger cabin does not decrease but increases and is more stable, which is also in the dangerous concentration range. Thus, adding vents cannot improve the safety of the passenger cabin. This is because the passenger cabin is closed under the original condition, and with more and more hydrogen entering the cabin, the cabin pressure gradually increases, which inhibits hydrogen from entering. As a result, there are concentration fluctuations. However, under Condition 2, after the vents are added, the original air can be exhausted by hydrogen coming through the vents, which will not lead to an increased pressure and but cause hydrogen to enter the cabin. Therefore, the hydrogen concentration in the passenger cabin does not decrease but increases.

In Condition 3, the sealing of the passenger cabin is maintained, and the vents are added directly to the fuel cell cabins. It can be seen from Figure 12 that the concentration of hydrogen entering the control cabin has still not improved significantly. Although the hydrogen in the passenger cabin has an obvious downward trend compared to those under Conditions 1 and 2, the 
hydrogen concentration is still within the explosion range. Therefore, under this ventilation condition, the security risks to the ship are still substantial.

Due to the fact that the hydrogen concentration has already decreased under Condition 3, further improvements are made based on this condition; namely, only the natural vents in the fuel cell cabins are replaced by mechanical vents. As shown in Figure 13, the concentration of hydrogen entering the control cabin dramatically reduces to below $4 \%$, and that entering the passenger cabin approaches zero. Under Condition 4, the hydrogen can be exhausted directly from the fuel cell cabins to the outboard area, and there is basically no hydrogen entering the control cabin and passenger cabin. As a result, the ship's safety is greatly improved. In addition, under this ventilation condition, the hydrogen concentration distribution can reach a steady state, within about $8 \mathrm{~s}$ (as shown in Figure 14), until the hydrogen stops leaking. In the entire process, the hydrogen only accumulates in the fuel cell cabins, and diffuses directly to the outboard area; therefore, both the control cabin and passenger cabin are in a safe area. In this case, as long as reliable anti-static and explosion-proof measures can be ensured in the fuel cell cabins, so that the crew can discover and cut off the hydrogen source promptly, any fire and explosion can be prevented. The potential hazard will not spread to the other cabins, and therefore a safe and reliable state can be achieved.

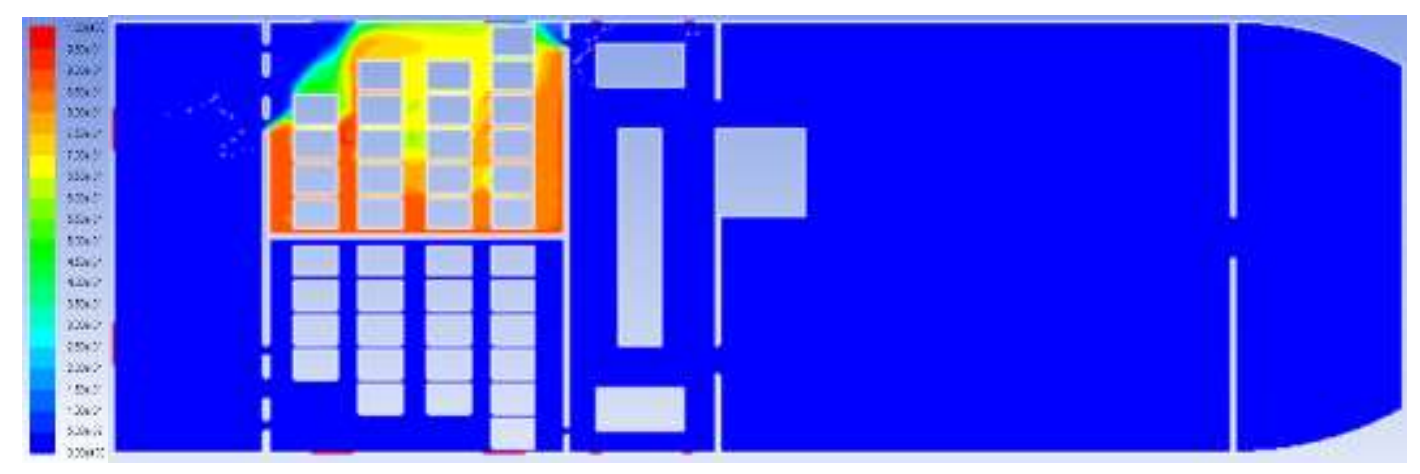

Figure 14. The steady state concentration distribution of hydrogen under Condition 4 


\section{Conclusions}

In this paper, by using a fuel cell ship as the research object, the hydrogen leakage diffusion process at different positions in fuel cell cabins was numerically simulated by Fluent software. Furthermore, the concentration distributions of hydrogen in the cabins under different ventilation conditions were analyzed. The following conclusions can be drawn.

1) Under the natural ventilation condition, the concentration of hydrogen in the cabin increases rapidly. At approximately $10 \mathrm{~s}$, the hydrogen fraction in the control cabin reaches to almost $100 \%$, and then maintains the same level. However, if the positive ventilation is taken, the hydrogen fraction in the control cabin would decline to $4 \%$, and the hydrogen fraction in the passenger cabin would decline to 0 .

2) The walls and corners of the fuel cell cabins are the areas where there will be a high concentration of hydrogen after a leakage, with a relatively high concentration being reached in a short time. As a result, the walls and corners are the best positions for hydrogen sensors. At the same time, hydrogen sensors should also be arranged at the entrances of the control cabin and passenger cabin.

3) The arranging of vents in the passenger cabin does not reduce the accumulated concentration of hydrogen in a cabin, but actually increases it. Thus, it is inappropriate to arrange vents in the passenger cabin. When a hydrogen leakage occurs, the windows and doors should not be opened and accordingly the inflow of hydrogen should be prevented.

4) The positioning of mechanical vents in the fuel cell cabins themselves is the best way to avoid the accumulation of hydrogen in cabins and the diffusion to the other cabins. However, appropriate security measures should be taken not only in the fuel cell cabins 
but also in the other cabins. Exhaust fans and other electrical equipment should be explosion-proof. Moreover, exposed plugs and wires should be kept to a minimum.

In this paper, some suggestions and guidelines are presented for the safety design of a fuel cell ship with regard to sensor layout and ventilation conditions. However, further research is needed on the layout of cabins. The rational layout design and structure optimization of multiple cabins in a fuel cell ship would affect the accumulation of hydrogen in cabins significantly; therefore, this will be the subject of future research by the authors.

\section{Acknowledgement}

This work is supported by the Research Project of Advanced Technology Ship (No: MIIT [2016]548), Hubei Provincial Leading High Talent Training Program Funded Project (File No. HBSTD[2012]86) and the self-determined and innovative research funds of Wuhan University of

Technology grant 2018-ND-C1-19.

\section{References}

[1] Xinping Yan. Progress Review of Renewable Energy Application in Ship. Ship and Ocean Engineering, 2010, 39(6): 111-115 (in Chinese).

[2] A. Miola, B. Ciuffo, E. Giovine, M. Marra. "Regulating Air Emissions from Ships," the State of the Art on Methodologies. Technologies and Policy Options, 2010: 978 992.

[3] A.B. Stambouli, E. Traversa. Fuel cells, an alternative to standard sources of energy. Renewable \& Sustainable Energy Reviews, 2002, 6(3): 295-304.

[4] Vicki P. McConnell. Now, voyager. The increasing marine use of fuel cells. Fuel Cells Bulletin, 2010, (5): 12-17.

[5] L. van Biert, M. Godjevac, K. Visser, et al. A review of fuel cell systems for maritime applications. Journal of Power Sources, 2016, 327(30): 345-364.

[6] One hundred passengers and zero emissions-The first ever passenger vessel to sail propelled by fuel cells. http://ec.europa.eu/environment/life/project/Projects/index.cfm?fuseaction= home.showFile\&rep=file\&fil=Zemships_Brochure_EN.pdf.

[7] E. Ovrum, G. Dimopoulos. A validated dynamic model of the first marine molten carbonate fuel cell. Applied Thermal Engineering, 2012, 35(1): 15-28.

[8] Fuel cell system on fellowship supply vessel is hybridized. Fuel Cells Bulletin, 2012: 3-4. 
[9] L.E. Klebanoff, J.W. Pratt, C.B. LaFleur. Comparison of the safety-related physical and combustion properties of liquid hydrogen and liquid natural gas in the context of the SFBREEZE high-speed fuel-cell ferry. International Journal of Hydrogen Energy, 2017, 42(1): 757-774.

[10] Feasibility of the SF-BREEZE: a Zero-Emission, Hydrogen Fuel Cell, High-Speed Passenger Ferry.https://www.marad.dot.gov/wp-content/uploads/pdf/SF-BREEZE-Ferry-FeasibilityStudy-Report-by-Sandia-National-Laboratory-2.pdf.

[11] Choudhury A, Chandra H, Arora A. Application of solid oxide fuel cell technology for power generation-A review. Renewable \& Sustainable Energy Reviews, 2013, 20(4): 430-442.

[12] Choi C H, Yu S, Han I S, et al. Development and demonstration of PEM fuel-cell-battery hybrid system for propulsion of tourist boat. International Journal of Hydrogen Energy, 2016, 41(5): 3591-3599.

[13] Zhu L, Han J, Peng D, et al. Fuzzy logic based energy management strategy for a fuel cell/battery/ultra-capacitor hybrid ship. International Conference on Green Energy. IEEE, 2014: 107-112.

[14] Bassam A M, Phillips A B, Turnock S R, et al. Development of a multi-scheme energy management strategy for a hybrid fuel cell driven passenger ship. International Journal of Hydrogen Energy, 2016, 42(1): 623-635.

[15] Bigdeli N. Optimal management of hybrid PV/fuel cell/battery power system: A comparison of optimal hybrid approaches. Renewable \& Sustainable Energy Reviews, 2015, 42(42): 377-393.

[16] Dudek M, Tomczyk P, Wygonik P, et al. Hybrid Fuel Cell - Battery System as a Main Power Unit for Small Unmanned Aerial Vehicles (UAV). International Journal of Electrochemical Science, 2013, 8(6): 8442-8463.

[17] Alaswad A, Baroutaji A, Achour H, et al. Developments in fuel cell technologies in the transport sector. International Journal of Hydrogen Energy, 2016, 41(37): 16499-16508.

[18] Han J, Charpentier J F, Tang T. An Energy Management System of a Fuel Cell/Battery Hybrid Boat. Energies, 2014, 7(5): 2799-2820.

[19] Shih N C, Weng B J, Lee J Y, et al. Development of a $20 \mathrm{~kW}$ generic hybrid fuel cell power system for small ships and underwater vehicles. International Journal of Hydrogen Energy, 2014, 39(25): 13894-13901.

[20] Ren H, Wu Q, Gao W, et al. Optimal operation of a grid-connected hybrid PV/fuel cell/battery energy system for residential applications. Energy, 2016, 113: 702-712.

[21] F. Vogler, G. Würsig. Fuel Cells in Maritime Applications Challenges Chances and Experiences. http://conference.ing.unipi.it/ichs2011/papers/158.pdf.

[22] Borman G.L., Ragland K.W. Combustion engineering. NewYork: McGraw-Hill, 1998.

[23] I. Herath, D. Madeley, B Bradshaw. Hydrogen Fuel Cell taxi: Safety analysis experiences. 4th IET International Conference on System Safety 2009. Incorporating the SaRS Annual Conference, November 2009.

[24] Y. Sato, H. Iwabuchi, M. Groethe, et al. Experiments on Hydrogen Deflagration. Asian Hydrogen Energy Conference, 2006, 159(1): 144-148.

[25] Prankul Middha, Olav R. Hansen, Idar E. Storvik. Validation of CFD-model for hydrogen dispersion. Journal of Loss Prevention in the Process Industries, 2009, 22 (6): 1034-1038.

[26] Michael R. Swain, Patrick Filoso, Eric S. Grilliot, et al. Hydrogen leakage into simple geometric enclosures. International Journal of Hydrogen Energy, 2003, 28(2): 229-248. 
[27] K. Takenoa, K. Okabayashia, A. Kouchia, T. Nonaka, et a1. Dispersion and explosion field tests for $40 \mathrm{MPa}$ pressurized hydrogen. International Journal of Hydrogen Energy, 2007, 32(13): 2144-2153.

[28] Shirvill C. L., Roberts P., Butler J. C., et a1. Characterisation of the hazards from jet releases of hydrogen. 2nd International Conference on Hydrogen Safety, 2007, Spain.

[29] Robert W. Schefer, Mark Groethe, William G. Houf, et al. Experimental evaluation of barrier walls for risk reduction of unintended hydrogen releases. International Journal of Hydrogen Energy, 2009, 34 (3): 1590-1606.

[30] D. Schmidt, U. Krause, U. Schmidtchen. Numerical simulation of hydrogen gas releases between buildings. International Journal of Hydrogen Energy, 1999, 24(5): 479-488.

[31] A.G. Venetsanos, D. Baraldi, P. Adams, et al. CFD modelling of hydrogen release, dispersion and combustion for automotive scenarios. Journal of Loss Prevention in the Process Industries, 2008, 21(2): 162-184.

[32] Fotis Rigas, Spyros Sklavounos. Evaluation of hazards associated with hydrogen storage facilities. International Journal of Hydrogen Energy, 2005, 30(13-14): 1501-1510.

[33] Héctor A. Olvera, Ahsan R. Choudhuri. Numerical simulation of hydrogen dispersion in the vicinity of a cubical building in stable stratified atmospheres. International Journal of Hydrogen Energy, 2006, 31(15): 2356-2369.

[34] H.Wilkening, D. Baraldi. CFD modelling of accidental hydrogen release from pipelines. International Journal of Hydrogen Energy, 2007, 32(13):2206-2215.

[35] Yanlei Liu, Yongquan Qin, Shuiping Sheng, et al. Numerical investigation on dispersion of hydrogen in hydrogen powered automobile. Journal of Safety Science and Technology, 2009, 5(5): 5-8. (in Chinese).

[36]Jingyuan Li, Yongzhi Zhao, Jinyang Zheng. Simulation and analysis on leakage and explosion of high pressure hydrogen in hydrogen refueling station. Journal of Zhejiang University(Engineering Science), 2015, 49(7): 1389-1394. (in Chinese).

[37] Jongrak Choi, Nahmkeon Hur, Seongwon Kang, et al. A CFD simulation of hydrogen dispersion for the hydrogen leakage from a fuel cell vehicle in an underground parking garage. International Journal of Hydrogen Energy, 2013,38 (19): 8084-8091.

[38]Eunjung Kim, Jaedeuk Park, Jae Hyun Cho, et al. Simulation of hydrogen leak and explosion for the safety design of hydrogen fueling station in Korea. International Journal of Hydrogen Energy, 2013, 38(3): 1737-1743.

[39] V. Molkov, D. Makarov, M. Bragin. Physics and modelling of under-expanded jets and hydrogen dispersion in atmosphere. Physics of Extreme State of Matter, 2009, 11(6): 143-145.

[40] John D. Anderson, JR. Computational Fluid Dynamics. McGraw Hill Education, 1995. 